\title{
DAKWAH ISLAM DI ERA GLOBALISASI: REVITALISASI PRINSIP MODERASI ISLAM
}

\author{
Dakwah in Globalization Era: \\ Revitalization of Islamic Moderation Principles
}

\author{
Hamzah Harun al-Rasyid \\ Universitas Islam Negeri Alauddin Makassar \\ J1. Sultan Alauddin No.36 Samata-Gowa \\ Email: hamzahharun@yahoo.com
}

\begin{abstract}
Abstrak
Dalam pandangan Islam, ajaran normatif yang tidak boleh berhenti untuk dilaksanakan oleh penganutnya adalah mengajak umat manusia kejalan yang baik dengan melakukan hal-hal yang makruf dan menghindari perkara-perkara yang buruk dan keji dan ini yang dimaksud dengan terma "Dakwah Islam". Menjalankan ajaran ini selalu menghadapi tantangan di semua babak sejarah terutama sekali di era globalisasi saat ini karena karakteristik-karakteristiknya yang unik. Penelitian ini akan membahas bagaimana cara menghadapi tantangan dakwah di era globalisasi dengan mengajukan gagasan revitalisasi prinsip moderasi Islam sebagai cara yang dapat menarik simpati komunitas dakwah baik dari kalangan muslim maupun nonmuslim. Penelitian ini bertujuan untuk mengungkapkan karakteristikkarakteristik era globalisasi yang berpotensi menjadi tantangan dakwah Islam kemudian mencoba mengemukakan prinsip moderasi Islam sebagai sebuah cara yang tepat untuk menghadapi tantangan yang dimaksud. Metode yang digunakan dalam penelitian ini ialah metode diskriptif-kualitatif dengan cara mencoba menggambarkan era globalisasi dengan spesifikasi spesifikasinya begitu pula prinsip moderasi Islam dengan menganalisis karya-karya atau artikel-artikel yang berbentuk naskah dan bukubuku yang terkait dengan isu yang dimaksud. Hasil penelitian ini menunjukkan bahwa era globalisasi adalah merupakan era yang sangat kompleks dan rumit dan sangat berbeda dengan zaman awal Islam, dan dengan demikian era ini mesti diperlakukan dengan perlakuan yang berbeda. Karena sifatnya yang sanga spesifik gerakan "Dakwah Islam" harus lebih merevitalisasi prinsip Moderasi Islam dalam menghadapi tantangan globalisasi.
\end{abstract}

Kata kunci: dakwah Islam, tantangan globalisasi, prinsip moderasi Islam

\begin{abstract}
In an Islamic view, the term "dakwah" or inviting human being to the good by doing right and preventing bad conduct is normative teachings that should be always held tightly by its adherents. However, implementing this teachings has alwaysfaced challenges, a lot more in globalization era. This research will discuss how to face the challenges of Dakwah in the globalization era by revitalizing principles of Islamic moderation as the path to attract to dakwahMuslims and non-Muslim community. This study aims to reveal the characteristics of globalization that could potentially challenge Islamic Dakwah. Study also tried to present the principles of Islamic moderation as an appropriate path to face the challenges mentioned. This research used qualitatif- descriptive method to describe the era of globalization characteristic as well as principles of Islamic moderation by analyzing articles and books related to the issue. The results of this study indicate that the era of globalization is an era that is more complex, more complicated than early days of Islam, and thus this era should be treated with different treatments. Because of its specific characteristics, the "Islamic Dakwah" movement should engage the principle of Islamic Moderation to face its challenges
\end{abstract}

Keywords: Islamic dakwah, globalization challenges, principles of Islamic moderation 


\section{PENDAHULUAN}

I slam adalah agama universal. Karakter universalitas Islam digambarkan dan dilukiskan dalam banyak ayat Alquran. Ia dihadirkan untuk memberi inspirasi (hidayah) bagi semua manusia yang hidup di muka bumi agar mereka menikmati kehidupan yang penuh dengan kebahagian hakiki dan abadi. Disamping menyeruh orang-orang beriman, Alquran sering sekali menyeruh manusia. Dengan demikian, manusia semuanya menjadi komunitas Alquran. Hal ini dilukiskan oleh banyak penulis arab dengan menyebutnya sebagai Alamiyyatul Islam.

Berdasarkan hakikat di atas, umat Islam kemudian diperintahkan untuk menyampaikan pesan-pesan Islam yang terkandung dalam Alquran. Perintah Ilahi ini kemudian dipopulerkan dengan istilah kewajiban berdakwah. Berdakwah dalam Islam bukan hanya sebagai kewajiban tapi ia juga merupakan sebuah ajaran normatif-universal karena ia satu-satunya kanal untuk menyampaikan pesan-pesan kebaikan.

Sebagai sebuah ajaran normatif, sebagaimana halnya ajaran-ajaran kebaikan lainnya, aktivitas atau gerakan dakwah tidak selamanya menuai sukses dan berjalan mulus, namun ia selalu menghadapi berbagai tantangan dan harus selalu siap menghadapi tantangan yang menghadangnya, terutama sekali di era yang serba kompleks saat ini, era dimana skat-skat (batas-batas) wilayah sudah tidak menjadi penghalang bagi komunitas dunia untuk saling berjejaring dan saling mempengaruhi dan inilah yang disebut dengan era globalisasi. Karena demikian, boleh dikata saat ini kita sedang menyaksikan pertarungan antara Universalitas Islam vs globalisasi dunia \{Alamiyyatul Islam Amam Aulamat al-Dunya).

Penelitian ini bertujuan untuk mengungkap apa sesungguhnya yang harus dibangun oleh setiap muslim dalam kesadaran dirinya dalam menghadapi kerumitaneraglobalisasidalamkaitannyadengannya dengan pengembangan dakwah. Kesadaran yang dimaksud ialah bahwa tugas dan peran suci yang harus diembannya adalah menarik hati setiap orang baik yang sudah mendeklarasikan dirinya sebagai muslim atau yang belum (non-muslim) untuk berIslam dengan baik dan benar. Peran strategis ini akan mengalami kendala yang luar biasa bila seorang dai tidak mampu membangun asumsi yang benar menyangkut karakter-karakter manusia moderen yang sudah terglobalkan. Manusia moderen adalah komunitas yang baru yang jauh berbeda dengan komunitas muslim yang hidup di zaman awalawal Islam. Oleh karena itu, gerakan dakwah harus menempuh cara, metode, strategi baru yang mampu berjalan seiring dengan perkembangan dunia global yang sangat dinamis.

Dalam konteks ini, moderasi Islam \{alwasatiyyah al-Islamiyyah) menjadi sebuah strategi yang harus menjadi instrumen vital yang membekali intelektualis seorang dai. Seorang dai harus mengadopsi pemahaman keagamaan yang ideal; pemahaman fleksibel, kondisional, dan realistis yang telah membuat perjuangan dakwah Nabi, sahabat, dan para tokoh Islam mengukir kesuksesan yang gemilang dalam dunia dakwah. Gerakan dakwah harus bersinergi dengan gerakan pemikiran (ijtihad) dan keterpisahan keduanya akan menjadi ancaman serius bagi gerakan dakwah di era global saat ini. Artikel ini merekomendasikan perlunya gerakan dakwah membangun konsep-konsep dakwah yang berdiri tegak di atas teori-teori qurani dan keilmuan Islam klasik yang masih relevan dengan zaman ini, seperti teori substansialisasi (alUmuru bi Maqasidiha), Kontekstualisasi (tagayyurul fatawi bitagayyuri al-azminati wa al-amkinah) dan rasionalisasi (ta'lil al-Ahkam).

\section{Kajian Pustaka}

Isu dakwah di era globalisasi sudah banyak ditulis dan dibincangkan oleh banyak pakar dan penulis muslim. Namun tulisan dan karya-karya itu banyak bersifat global dan hampir tidak ada yang mengaitkannya dengan isu revitalisasi prinsip moderasi Islam sebagai sebuah cara yang sesuai untuk menarik simpati komunitas dakwah.

Yusuf Qaradawi misalnya dalam karyanya Islam dan Globalisasi Dunia hanya membeberkan bagaimana karakter dan bahaya globalisasi dunia yang sedang dimotori oleh Amerika terhadap dunia Islam seperti serangan pemikiran dan budaya (Gazwul Fikri). Begitu juga misalnya dengan Maryam Jamilah yang menulis buku Islam dalam kancah modernisme. Buku itu hanya menggambarkan tantangan modernisme terhadap Islam tanpa membincangkan prinsip moderasi Islam sebagai sebuah senjata untuk menghadapi tantangan yang dimaksud.

\section{Metode Penelitian}

Dakwah yang dimaksud dalam penelitian ini adalah upaya memperbaiki kondisi dan realitas manusia-muslim dan non-muslim berdasarkan 
nilai-nilai dan ajaran-ajaran Islam, baik secara teoritis maupun praktis. Dengan demikian, dakwah tidak hanya dilakukan melalui cara-cara klasik tapi juga melalui media modern yakni dengan cara mengemukakan kandungan dakwah melalui tulisan, buku, majalah dan internet. Dengan demikian, seorang dosen, guru, ilmuan adalah bagian dari gerakan dan misi dakwah.

\section{PEMBAHASAN}

\section{Potret Era Globalisasi}

Era globalisasi sering digambarkan sebagai sebuah babak sejarah dimana setiap negara beserta individunya harus mampu bersaing satu sama lain baik antar negara maupun antar individu. Persaingan yang terjadi di era ini memiliki pengaruh dan dampak yang negatif jika dicermati dengan seksama. Globalisasi memang menjadi lokomotif perubahan tata dunia yang tentu saja akan menarik gerbong-gerbongnya yang berisi budaya, pemikiran maupun materi. Ada beberapa dampak negatif globalisasi yang digulirkan oleh dunia Barat yang sangat berpotensi mempengaruhi kehidupan seorang muslim, dan sekaligus menjadi tantangan dakwah di era globalisasi, yakini:

Pertama, kecenderungan maddiyyah (materialisme).

Kedua, adanya proses individualisasi. Kehidupan kolektif, kebersamaan, gotong royong, telah diganti dengan semangat individualisme yang kuat.

Ketiga, sekulerisme yang senantiasa memisahkan kehidupan agama dengan urusan masyarakat, karena agama dinilai hanya persoalan privat antar individu semata.

Keempat, munculnya relativitas norma-norma etika, moral, dan akhlak. Sehingga dalam suatu konteks masyarakat yang dianggap tabu bisa saja dalam konteks masyarakat yang lain dianggap boleh (Amin Rais, 1998: 65-66)

Ali Syari'ati mengatakan, bahwa bahaya yang paling besar yang dihadapi oleh umat manusia zaman sekarang ini bukanlah ledakan bom atom, tetapi perubahan fitrah (Ari Ginanjar Agustian, 2002: xiii). Unsur kemanusiaan dalam dirinya sedang mengalami kehancuran sedemikian cepat, inilah mesin-mesin berbentuk manusia yang tidak sesuai dengan kehendak Tuhan dan kehendak alam yang fitrah.

Dampak globalisasi terhadap dunia dakwah sangat dirasakan. Banyak kasus yang muncul, misalnya pergaulan bebas, persoalan miras, narkoba, dan lain-lain, semua hal ini dikarenakan sebuah pemujaan terhadap kebebasan pribadi yang tidak lagi mengindahkan nilai-nilai agama. Sehingga dampaknya ternyata bukan hanya menimpa dirinya sendiri, tetapi juga terhadap masyarakat yang lain. Oleh karena itu, nilai-nilai negatif tersebut haruslah dinetralisir dengan nilai-nilai luhur ajaran Islam yang sangat menekankan keseimbangan kehidupan. Sikap seorang muslim dalam menghadapi kehidupan adalah dengan tetap istiqamah dalam hidayah Allah swt. untuk menjalankan kenikmatan agama Islam secara kaffah, bukan malah menggantinya dengan kekufuran yang akan menyebabkan kerugian dirinya sendiri seperti yang Allah firmankan dalam QS. Ibrahim (14): 28-29:

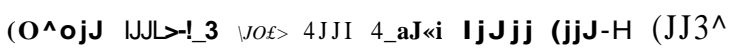

Tidakkah kamu perhatikan hrang-orang yang 'telah menukar ni'mat Allah dengan kekafiran dan menjatuhkan kaumnya ke lembah kebinasaan?, yaitu neraka Jahannam; mereka masuk ke dalamnya; dan itulah seburuk-buruk tempat kediaman.

Globalisasi perspektif Yusuf al-Qaradawi adalah upaya melenyapkan dinding dan jarak antara satu bangsa dengan bangsa lain, dan antara satu kebudayaan dengan kebudayaan yang lain. Sehingga, semuanya menjadi dekat dengan kebudayaan dunia, pasar dunia dan keluarga dunia (Yusuf al-Qardhawi, 2001: 21). Dengan kata lain globalisasi ialah suatu proses membuka keadaan, atau sebuah proses yang berjalan dan bertujuan menjadikan negara-negara di dunia bagaikaan satu unit. Masih kata Yusuf al-Qardhawi, bahwa terdapat perbedaan mendasar antara makna globalisasi (al-'aulamah) yang dipahami dunia barat pada hari ini dengan makna globalisasi (al-'alamiah) yang dimaksudkan oleh Islam. Menurtu dia, Universalitas Islam merujuk kepada ayat QS. Al-Anbiya (21): 107:

Dan tidaklah Kami mengutus kamu, melainkan sebagai rahmat bagi semesta alam.

Globalisasi atau al-alamiah yang dipahami oleh Islam adalah sesuatu yang berasaskan nilainilai penghormatan dan persamaan kepada seluruh manusia,(QS. Al-Isra: 70) bahwa setiap manusia memiliki hak dan tanggung jawab yang sama dihadapan Allah swt. Hal ini berbeda dengan pemahaman Barat mengenai globalisasi 
(al-'aulamah) sekarang ini, yang mengartikannya sebagai keharusan untuk menguasai secara politik, ekonomi, kebudayaan, dan sosio-kultural masyarakat agar sejalan dengan kepentingan Negara-negara Barat yang disponsori oleh Amerika. Penguasaan tersebut kemudian diarahkan lebih fokus lagi pada penguasaan Barat terhadap tatanan dunia Islam ( Yusuf al-Qardhawi, 2001:21).

Pengaruh globalisasi terhadap dunia pada dasarnya dapat dibagi menjadi tiga bagian utama, yaitu:

Pertama, globalisasi politik yang dimulai dari berakhirnya perang dunia kedua dan dimulainya perang dingin antara kekuatan-kekuatan besar di dunia untuk saling memperebutkan otoritas, pengaruh, hegemoni dan perebutan sumber ekonomi dan pasar internasional serta perang peradaban dan kultural di dunia global yang tak terbatasi lagi oleh wilayah teritorial. Berakhirnya perang dingin merupakan awal bagi era globalisasi dalam arti yang sebenarnya.

Kedua, Globalisasi Ekonomi. - Menurut Jamaluddin 'Atiyah, yang dimaksud dengan globalisasi di bidang ekonomi ialah menyatukan seluruh dunia kepada satu pasar bebas (free market) atau pemindahan kepemilikan umum dan perseroan-perseroan kepemilikan khusus untuk mengurangi pengawasan dan campur tangan pemerintah dalam negeri (Jamaluddin Atiyyah, 2002: 52). Dengan tatanan ekonomi baru yang oleh dunia Barat disebut dengan globalisasi atau pasar besar, mereka menjanjikan dunia dimana setiap orang menjadi pintar dan kaya. Tapi kenyataan yang terjadi adalah negara-negara maju dengan perusahaan-perusahaan besarnya menjadikan tatanan ekonomi baru yang disebut dengan globalisasi atau pasar bebas sebagai penjajahan model baru.

Ketiga, globalisasi sosial dan budaya. Pengaruh globalisasi telah masuk ke dalam seluruh kehidupan masyarakat, serta menghilangkan sekatsekat geografis antara satu negara dengan negara yang lain, antara satu budaya dengan budaya yang lain. Dengan menggunakan istilah "kebudayaan internasional" atau "modernisme", Barat yang dimotori oleh Eropa dan Amerika secara gigih mengekspor kebudayaan mereka ke belahan dunia yang lain. Dengan isu globalisasi ini, Barat ingin mewajibkan model, pemikiran, perilaku, nilai, gaya dan pola konsumsinya terhadap bangsa lain. Sedangkan orang-orang Perancis memandang bahwa globalisasi adalah wujud halus dari
Amerikanisasi yang mewujud dalam tiga simbol: (1) kepemimpinan bahasa Inggris sebagai bahasa kemajuan dan globalisasi, (2) dominasi filmfilm Hollywood dengan ide-ide rendah namun fasilitas yang fantastik, dan (3) minuman Cocacola, sepotong burger dan Kentucky-nya ( Maryam Jamilah, 1983:84).

Tetapi yang lebih penting dari semua itu adalah globalisasi pemikiran (gazwul fikri) atau perang pemikiran sebagai hasil daripada perkembangan teknologi dan informasi khususnya televesi dan internet. Dibandingkan dengan perang fisik atau militer, maka ghazwul fikri ini memiliki beberapa keunggulan. Antaranya ialah: Pertama, dana yang diperlukan tidak sebesar dana yang diperlukan untuk perang fisik. Kedua, sasaran daripada ghazwul fikri ini tidak terbatas. Ketiga, serangannya dapat mengenai siapa saja, dimana saja dan kapan saja. keempat, tidak ada korban dari pihak penyerang. Kelima, korban tidak merasakan bahwa sesungguhnya dirinya dalam kondisi diserang. Keenam, kesan yang dihasilkan sangat fatal dan berjangka panjang. Ketujuh, efektif dan efisien (Abdul Halim El-Muhammady, 1992: 95).

Dengan demikian, gerakan dan lembaga atau insitusi dakwah mesti mempertimbangkan kondisi real ini dalam mengemban misi dakwah di era globalisasi dan bagaimana metode dakwah yang diterapkan di era globalisasi. Kecangggihan dan kemoderenan globalisasi harus dijawab dengan dakwah yang canggih dan modern, bukan dengan dakwah konvensional.

\section{Kerumitan Gerakan Dakwah di Era Globalisasi}

Untuk menguji kesuksesan sebuah gerakan atau misi dakwah, maka unsur zaman merupakan isu penting yang menarik dibicarakan. Kita dapat mengatakan bahwa kej ayaan atau kesuksesan dakwah sangat tergantung pada kemampuan seorang dai atau gerakan dakwah memahami konstruk zaman dengan berbagai karakater dan problematikanya. Pada konteks ini, dapat dikatakan bahwa kej ayaan dakwa di masa lalu karena gerakan dakwah telah berhasil memahami karakter zamannya. Yang pasti adalah kondisi dan karakter zaman awal Islam sangat jauh berbeda dengan zaman sekarang yang kemudian disebut dengan era global. Era sekarang adalah era revolusi informasi dan komunikasi, era kemajuan sains dan teknologi.

Tantangan dakwah yang amat kompleks dewasa ini dapat dilihat dari minimal dari tiga perspektif, yaitu: 
Pertama, perspektif prilaku (behaviouristic perspective). Salah satu tujuan dakwah adalah terjadinya perubahan prilaku (behaviour change) pada masyarakat yang menjadi obyek dakwah kepada situasi yang lebih baik. Tampaknya, sikap dan prilaku (behaviour) masyarakat dewasa ini hampir dapat dipastikan lebih banyak dipengaruhi oleh keadaan sekitarnya.

Kedua, tantangan dakwah dalam perspektif transmisi (transmissionalperspective). Dakwah dapat diartikan sebagai proses penyampaian atau transmisi ajaran agama Islam dari da'i sebagai sumber kepada masyarakat dakwah sebagai penerima. Ketika ajaran agama ditrasmisikan kepada masyarakat yang menjadi obyek, maka peranan media sangat menentukan. Ziauddin Sardar mengemukakan bahwa abad informasi ternyata telah menghasilkan sejumlah problem besar. Menurutnya, bagi dunia Islam, revolusi informasi menghadirkan tantangantantangan khusus yang harus diatasi, agar umat Islam harus bisa memanfaatkannya untuk mencapai tujuan dakwah (Ziauddin Sardar, 1996: 16-17).

Ketiga, tantangan dakwah perspektif interaksi. Ketika dakwah dilihat sebagai bentuk komunikasi yang khas (komunikasi Islami), maka dengan sendirinya interaksi sosial akan terjadi, dan di dalamnya terbentuk norma-norma tertentu sesuai pesan-pesan dakwah. Yang menjadi tantangan dakwah dewasa ini, adalah bahwa pada saat yang sama masyarakat yang menjadi obyek dakwah pasti berinteraksi dengan pihak-pihak lain atau masyarakat sekitarnya yang belum tentu membawa pesan yang baik, bahkan mungkin sebaliknya.

\section{Moderasi Islam dan Kesuksesan Gerakan Dakwah Potret Moderasi Islam}

Pada hakikatnya, perubahan zaman akan mempengaruhi perubahan sosial atau perlakuan masyarakat terhadap institusi zaman dengan berbagai kerumitan atau problematika kehidupan yang melingkupinya. Kecanggihan media turut mempengaruhi tingkat dan cara berpikir masyarakat moderen, sehingga banyak orang mengkategorikan zaman ini sebagai zaman pemikiran dan filsafat sehingga masyarakat moderen cenderung mempertanyakan segala yang ada termasuk nilai dan ajaran-ajaran agama. Kondisi ini mengharuskan setiap dai, ulama, harus menjelaskan pemikiranpemikiran keagamaan dengan cara yang sesuai dengan kondisi dan karakter zaman seperti yang sudah disinggung sebelumnya. Sejatinya ini tidak menjadi problem bagi dakwah Islamiyyah, karena
Islam sesungguhnya adalah agama yang rasional dan filosofis yang sejak awal bisa dideteksi melalui ajakan Alquran dengan bentuk yang cukup berfariasi untuk bernkir mendalam mengenai isu-isu penting dalam kehidupan ini termasuk di dalamnya masalah ketuhanan, kemanusiaan, dan kehidupan. Dengan demikian memperkenalkan Islam dengan menggunakan logika-logika Islam dan ide-ide moral yang universal merupakan bagian dari proses moderasi Islam yang merupakan ciri khas atau karakter Islam. Moderasi Islam menghendaki seorang dai untuk tidak hanya melihat teks-teks suci, tapi harus juga mempertimbangkan konteks sosial masyarakat dakwah. Dan ini merupakan metode Alquran dalam membangun masyarakat dakwah. Bukan hanya itu tapi sikap moderat mengharuskan seseorang untuk membuka kran rasionalisasi ajaran Islam dalam arti harus mengemukakan nilai dan ajaran Islam dengan mengaitkan dengan rahasiarahasia atau hikmah-hikmah yang ada di balik ajaran-ajaran Islam.

Kalau kita merujuk kepada Alquran sebagai acuan ekspresi keberagamaan baik pada level pemahaman maupun penerapan, maka secara eksplisit ia menegaskan eksistensi umat moderat (Ummatan Wasathan). Hal ini dapat dilihat misalnya dalam QS al-Baqarah ayat 143 dan ayat sebelumnya " Shiratan Mustaqiman" dan QS Ali Imran ayat 111. Ayat-ayat yang dimaksud menjadi referensi bagi banyak ilmuan dalam membangun ajaran moderasi dalam Islam.

Berdasarkan kenyataan diatas, maka harus ditegaskan lebih awal bahwa ketika artikel ini menganjurkan dan merevitalisasi prinsip alwashatiyyah sebagai acuan dalam melakukan gerakan dakwah maka ia memaknainya dengan mengacu pada esensi dan substansi yang dikandungnya. Apa lagi substansi "Moderasi" memiliki akar yang jelas dalam sumber Islam yaitu Alquran dan Sunnah Nabi. Berangkat dari hal itu, maka memberi pengertian apa yang dimaksud moderasi Islam sangat perlu untuk menghindari kekeliruan dalam memahami Artikel ini..

Moderasi Islam adalah sebuah pandangan atau sikap yang selalu berusaha mengambil posisi tengah dari dua sikap yang berseberangan dan berlebihan sehingga salah satu dari kedua sikap yang dimaksud tidak mendominasi dalam pikiran dan sikap seseorang. Dengan kata lain seorang muslim moderat adalah muslim yang memberi setiap nilai atau aspek yang berseberangan bagian tertentu tidak lebih dari porsi yang semestinya. Karena 
manusia-siapa pun ia-tidak mampu melepaskan dirinya dari pengaruh dan bias baik pengaruh tradisi, pikiran, keluarga, zaman dan tempatnya, maka ia tidak mungkin merepresentasikan atau mempersembahkan moderasi penuh dalam dunia nyata. Yang mampu melakukan hal itu adalah hanya Allah (Yusuf al-Qaradhawi, 2007: 50).

Kehadiran Islam sebagai agama adalah untuk menarik manusia dari sikap ekstrim yang berlebihan dan memposisikannya pada posisi yang seimbang. Maka dalam ajaran-ajaran Islam terdapat unsur rabbaniyyah (ketuhanan) dan Insaniyyah (kemanusiaan), mengkombinasi antara Maddiyyah (materialisme) dan ruhiyyah (spiritualisme), menggabungkan antara wahyu (revelation) dan akal (reason), antara maslahah ammah (al-jamaaiyyah) dan maslahah individu (al-fardiyyah), dan lainlain sebagainya. Konsekwensi dari moderasi Islam sebagai agama, maka tidak satupun unsur atau hakikat-hakikat yang disebutkan diatas dirugikan (Yusuf al-Qaradhawi, 2007: 50).

Ajaran moderasi yang disampaikan oleh Islam melalui Alquran dan Sunnah Nabi mengalami kristalisasi dalam interaksi-interaksi sosial Nabi, para sahabatnya dan ulama-ulama yang datang kemudian. Meskipun dalam prakteknya sahabat Nabi sendiri kadang-kadang mengekspresikan keberagamaannya tidak sejalan dengan ajaran washatiyyah sebagaimana mestinya. Bukan hanya periode Nabi, distorsi terhadap moderasi Islam juga terjadi pada generasi selanjutnya. Kelompok khawarij yang kemudian dilanjutkan oleh kelompok zahiriyyah merupakan bentuk eksperesi keagamaan yang bisa merepresentasikan pemahaman keagamaan yang tidak moderat.

Dengan demikian, maka kita dapat mengatakan bahwa pemahaman atau sikap ekstrim atau berlebihan dalam memahami dan mengeksekusi ajaran dan pesan-pesan Islam merupakan tantangan bagi moderasi Islam di semua zaman dengan level atau tingkatan yang berbeda. Oleh karena itulah, layak untuk kita mengatakan bahwa peran yang harus dimainkan oleh institusi dakwah dengan seluruh unsurnya yang penting yakni seluruh ulama, ilmuan, cendikiawan muslim adalah merevitalisasi dan memperkokoh wacana moderasi Islam di semua level keilmuan.

Sebelum kita melihat lebih jauh pandangan ulama Islam menyangkut moderasi Islam, maka secara umum dapat dikatakan bahwa faktor penting yang telah menjadi pemicu terbentuknya moderasi Islam sejak dulu sampai sekarang adalah pengakuan adanya dialektika antara wahyu, akal (maslahat), dan realita. Sikap seorang dai dan ulama yang mengakui adanya sentralisasi teks dalam arti bahwa teks adalah sumber dan mekanisme ijtihad yang hampa dari maksud tertentu dan tidak mengandung ide moral maka ia akan berpotensi untuk memproduk pemahaman keagamaan yang bernuansa radikal. Karena hasil ijtihad yang bersumber dari pemisahan teks dari ide moral yang dikandungnya (kemaslahatan, keadilah, persamaan, kerahmatan), maka ijtihad itu lepas dari unsur dan nilai humanistik dan hanya dipenuhi oleh nilai ketuhanan. Berpihak kepada nilai ketuhanan dengan cara menampakkan keberpihakan kepada wahyu secara ekstrim tanpa ingin memberi porsi bagi nilai kemaslahatan manusia itulah sesungguhnya embrio dari munculnya radikalisme dalam memahami dan menerapkan pesan agama.

Sisi lain yang dapat memicu munculnya sikap moderat dalam diri seorang dai adalah pengakuannya terhadap posisi realitas kehidupan dan teks-teks secara seimbang. Kesiapan dan kemampuan seseorang melibatkan realitas dalam proses pembacaan atau pemahaman teks-teks suci merupakan bagian dari terbentuknya sikap moderat. Dalam wacana hukum Islam istitusi "realitas" sering sekali dijabarkan dalam bentuk kebutuhan dan tuntutan zaman, tempat, kondisi dan orang. Keinginan seorang muslim (terutama ilmuan Islam) untuk memahami dengan baik dan benar zaman yang ia hidupi dan orang beraktifitas, kondisi manusia, orang yang melakukan ajaran-ajaran Islam kemudian melibatkannya dalam memahami teksteks suci adalah potensi utama bagi munculnya moderasi Islam.

Salah satu contoh yang bisa menjadi sampel kurangnya apresiasi terhadap realitas dalam memahami dan menerapkan pesan teks-teks suci adalah kisah perbedaan pendapat yang terjadi antara Abdullah bin Umar dan anaknya Bilal (Muhammad Mustafa Shalabi, 1945: 34). Suatu ketika Abdullah menyampaikan kepada anaknya sebuah riwayat dari Nabi mengenai perempuan dan salat jamaah di mesjid. Kata Ibnu Umar, berdasarkan sabda Nabi (teks) perempuan tidak boleh dilarang pergi ke mesjid. Hadis itu bunyinya : "Laa Tamna'uu Nisaa'akum al-Masaajida". 'Ibnu Umar tampaknya ingin hadis itu diamalkan pada zaman ia hidup meskipun di zamannya sudah terjadi perubahan sosial yang cukup signifikan berbeda dengan 
kondisi di zaman Nabi. Ia tidak berusaha mencoba mendialogkan zamannya dengan zaman Nabi. Berbeda dengan Ibnu Umar, Bilal anaknya ternyata punya sensitifitas dengan perubahan zamannya, ia cukup mengerti dengan realitas kehidupan zamannya.

Berangkat dari kesadarannya atas perubahan zaman yang dihidupinya, Bilal dengan lantang mengatakan kepada bapaknya, "hadis itu sudah tidak relevan lagi untuk diterapkan zaman sekarang". Kata dia, perempuan-perempuan sekarang harus dilarang ke Mesjid. Pernyataan yang cukup berani itu membuat bapaknya marah. Dalam sebuah riwayat, Ibnu Umar karena saking marahnya, langsung memukul wajah anaknya. Sudah bisa ditebak, kemarahan Ibnu Umar karena Bilal berani menggugat teks Nabi sebagai sumber primer. Bagi Ibnu Umar, tidak ada" argumen yang bisa digunakan di depan sebuah teks.

Berangkat dari penjelasan yang sudah dikemukakan sebelumnya, maka dapat dikatakan bahwa apa yang dilakukan oleh Ibnu Umar adalah bagian dari pemahaman atau sikap yang tidak mencerminkan moderasi Islam. Penyebabnya adalah ia tidak mencoba mengungkap realitas sosial pada saat hadis (teks) itu dituturkan oleh Nabi. Seperti yang sudah dikemukakan bahwa memahami teksapakah itu Alquran atau pun hadis- dan melepaskan dari konteksnya adalah salah satu faktor atau potensi sikap radikal. Untuk memudahkan pemahaman bagi kasus Ibnu Umar dan anaknya, sebaiknya kita membandingkannya dengan kasus ziarah kubur yang tadinya dilarang oleh Nabi dan pada akhirnya diizinkan karena larangan yang terjadi sebelumnya memiliki konteksnya tersendiri yang berbeda ketika pembolehan itu dikeluarkan oleh Nabi.

Apa yang dituduhkan oleh Ibnu Umar terhadap anaknya yaitu kelancangannya menggugat dan melecehkan teks ternyata tidak realistis dan kurang beralasan. Berdasarkan riwayat, perbedaan yang terjadi antara Ibnu Umar dan anaknya seputar masalah tadi ternyata sampai di telinga Aisyah. Pada saat Aisyah mengetahui perdebatan itu, Aisyah kemudian mengeluarkan pernyataan yang cukup menarik dan sedikit mengagetkan. Aisyah mengatakan, "Andai saja Rasulullah masih hidup dan melihat bagaimana ulah dan perilaku perempuan-perempuan sekarang niscaya Nabi akan merubah pendapatnya dan pastilah beliau melarang perempuan pergi ke mesjid".

JJ>LMJ,I $i^{\wedge} x j X$ fJJjl fLtolII 4iLti la (jyiJI $i S^{\wedge} J 3^{\wedge}$
Berdasarkan pembelaan Aisyah bagi Bilal, kiranya dapat dipahami sebab perbedaan antara bilal dan bapaknya mengenai masalah ini yaitu perbedaan keduanya mengapresiasi realitas sosial dan pengaruhnya bagi pengembangan atau perubahan hukum yang dikandung oleh sebuah teks.

Dari keterangan di atas kiranya dapat disimpulkan bahwa kurangnya pengetahuan mengenai dinamika realitas kehidupan dan tidak adanya pengakuan terhadap pengaruh yang bisa ditimbulkan oleh dinamika itu terhadap pemahaman dan penerapan pesan teks-teks suci merupakan potensi besar bagi pemahaman dan prilaku keislaman yang radikal dan tentu tantangan besar bagi tumbuh-kembangnya moderasi Islam.

Dengan demikian, perlu ditegaskan sejak awal bahwa kesuksesan, keberhasilan dan kejayaaan misi, institusi, gerakan dan lembaga dakwah di era ini adalah tergantung pada kemampuannya membangun tipe fiqih dakwah yang selalu memperhatikan dan meng-update informasiinformasi aktual berkaitan dengan kondisi sosial dan kemampuan masyarakatnya kemudian mengemukakan atau menjelaskan misi-misi agama berdasarkan kondisi-kondisi zaman yang sudah dipahaminya dengan benar dan sempurna.

\section{Moderasi Islam dalam Alquran}

Pada beberapa ayat Alquran, Allah swt. Memberi petunjuk pelaksanaan bagi pembumian moderasi Islam, yang paling menonjol adalah fleksibilitas Alquran melalui pengakuaannya terhadap kondisi yang berfariasi yang selalu mengiringi kehidupan manusia. Pada waktu tertentu manusia mengalami kondisi normal dan pada waktu lain ia mengalami perubahan kondisi menjadi tidak normal. Dalam terminologi Alquran disebut dengan kondisi dharurah. Pengakuan Alquran terhadap kondisi dharurah manusia sebagai eksekutor ajaran dan pesan ilahi merupakan pondasi yang sangat kokoh bagi berkembangnya moderasi Islam, karena konsep dharurah adalah terjemahan bagi keberpihakan Islam terhadap kemanusiaan. Alquran memberi penegasan bagi otoritas dharurah dalam pelaksanaan hukum Islam dalam banyak kesempatan termasuk diantaranya firman-Nya "Tetapi barangsiapa dalam keadaan terpaksa (memakannya) sedang dia tidak menginginkannya dan tidak (pula) melampaui batas, maka tidak ada dosa baginya. Sesungguhnya Allah Maha Pengampun lagi Maha Penyayang". Hal ini dapat dilihat pada QS 
al-Baqarah ayat 173 dan QS al-Maidah ayat 3 begitu pula QS al-An'am ayat 119, 145 dan QS al-Nahl : 115.

Dalam konteks yang lain, Alquran mengemukakan otoritas dharurah dalam mempengaruhi hukum. Allah berfirman "Barangsiapa yang kafir kepada Allah sesudah dia beriman (dia mendapat kemurkaan Allah), kecuali orang yang dipaksa kafir padahal hatinya tetap tenang dalam beriman (dia tidak berdosa), akan tetapi orang yang melapangkan dadanya untuk kekafiran, maka kemurkaan Allah menimpanya dan baginya azab yang besar (QS al-Nahl ayat 106 ).

Wacana moderasi dengan perangkat dharurah yang telah dibangun kokoh dalam Alquran mengalami konseptualisasi yang mengagumkan dalam tradisi pakar hukum Islam. Pengakuan mereka terhadap konsep dharurah sangat tinggi, hukum bagi mereka-bagaimana pun kuatnya-tidak mampu bertahan di hadapan kondisi keterpaksaan yang dialami oleh manusia. Dalam tradisi fiqih kondisi dharurah dapat menggugurkan kewajiban dan membolehkan larangan-larangan (alMahzurdt). Banyak kaidah yang telah dirumuskan oleh pakar hukum Islam untuk mempertajam konsep dharurah sekaligus menjadi indikator atas apresiasi dan keberpihakan terhadap kemanusiaan (kemaslahatan). Kaidah-kaidah itu sebagai berikut;

1. Segala bentuk kemudaratan harus ditiadakan (al-Dhararu Yuzal)

2. Kemudaratan tidak boleh ditiadakan dengan cara menciptakan kemudaratan baru (al-Dhararu Id Yuzdlu bi al-Dharari)

3. Kondisi-kondisi darurat yang dialami oleh manusia membolehkannya untuk melakukan hal-hal yang dilarang dalam agama (al-Darurat Tubihul Mahzurdt).

4. Larangan yang dapat dilakukan disebabkan karena kondisi darurat dibatasi pada kadar darurat itu sendiri (al-Daruratu Tuqaddaru bi qadariha) (Imam al-Suyuti, $1403: 83$ ).

Yang menarik dalam wacana dharurah sebagai pilar moderasi Islam adalah posisi "kebutuhan" yang disetarakan dengan "dharurah". Artinya, fleksibilitas hukum Islam tidak hanya dipengaruhi oleh kondisi keterpaksaan tapi kebutuhan yang mendesak pun mampu melenturkan hukum Islam. Kaidah yang dirumuskan untuk menopang ketentuan ini adalah al-Hdjatu Tunazzalu manzilat al-Darurat 'ammatan kdnat aw khassah (Imam al-Suyuti, 1403: 83).

Konsep ini juga banyak mewarnai perkembangan hukum dalam Islam. Dalam wacana fiqih klasik, salah satu sampel yang dapat menjadi terapan teori otoritas kebutuhan adalah transaksi jual beli yang tidak menghadirkan barang pada saat transaksi yang dalam fiqih disebut dengan Bai'u alSalam atau Aqdu al-Istishnaa. Sementara salah satu standar (ketentuan) bagi legalitas atau keabsahan transaksi jual beli adalah barang dan harga harus diserahkan pada saat transaksi, dan ketentuan ini diberlakukan untuk menghindari terciptanya riba. Transaksi istishnaa dan jual beli salam masingmasing merupakan transaksi dimana barang tidak diserahkan pada saat transaksi, lagi-lagi kedua bentuk transaksi ini dibolehkan, meskipun melanggar ketentuan umum, karena keduanya merupakan kebutuhan umum masyarakat, sehingga bila ia tidak dibolehkan sangat berpotensi untuk menciptakan stagnasi ekonomi masyarakat, sehingga bisa dibayangkan misalnya betapa beresikonya kalau pemesanan-pemesanan barang seperti mobil tidak dibolehkan. Dalam konteks kekinian, tidak sedikit ilmuan membolehkan untuk berinteraksi dengan bank-bank konvensional, meskipun bank-bank itu menerapkan sistem bunga (riba), hanya karena salah satu alasannya bahwa berinteraksi dengan bank-bank itu merupakan kebutuhan mendesak dan belum sampai pada level darurat. Perlu dikemukakan bahwa Mayoritas ulama memakai standar terancamnya nyawa seseorang atau terjadinya luka pada anggota badannya untuk menandai terjadinya darurat.

\section{Dakwah Dan Fiqih Moderat}

Perangkat yang tidak kalah pentingnya dalam memajukan dan menumbuh-kembangkan misi dakwah sekaligus menjadi icon besar bagi moderasi yang dimaksud adalah fiqih al-Taysir.

Fiqih al-Taysir adalah fiqih yangmemposisikan hukum Islam sebagai hukum yang bertujuan untuk mendidik manusia bukan menyiksanya. Fiqih ini memahami bahwa ketika manusia merasa sempit perasaannya dan mengalami kesulitan dalam menjalankan pesan hukum, maka ia harus diberi kemudahan sesuai ketentuan yang berlaku dalam agama. Fiqih ini tidak seperti yang disalahpahami oleh segelintir orang bahwa ia merupakan upaya menundukkan teks-teks suci untuk ditafsirkan atau diinterpretasi sesuai dengan apa yang dianggap mudah oleh hawa nafsu,. tapi fiqih ini adalah upaya mencari pendapat yang paling mudah dari berbagai pendapat fiqih yang ada karena pendapat itulah yang sesuai dengan kemaslahatan manusia (mashlahah syar'iyyah). Mencari atau memilih yang 
mudah dari pilihan-pilihan yang ada bukanlah sesuatu yang baru dalam Islam. Fiqih al-Taysir telah dibangun oleh Alquran- dan Sunnah. Betapa banyak ayat dalam Alquran yang menginformasikan bahwa Allah menginginkan kemudahan bukan kesusahan bagi hambanya. Berdasarkan riwayat Aisyah, Rasulullah selalu memilih yang mudah dari dua perkara yang ditawarkan kepadanya (red: Maa Khuyyira Rasulullahi Baina Amraini Illaa khataara Aysarahuma) (HR al-Bukhari No: 3367). Salah satu rumusan kaidah fiqih yang sangat tepat untuk dikemukakan dalam hal moderasi Islam dan relevansinya dengan fiqih al-Taysir adalalah rumusan kaidah yang dikonstruk oleh Imam alGazali yaitu Idzd Dhdqa al-Amru ittasaa Wa Idzd ittaa'a al-Amru Dhdqa (apa bila perkaranya menjadi sempit maka perkara itu harus diperluas dan apabia perkaranya menjadi luas maka perkara itu harus dipersempit). Potongan pertama kaidah ini mencerminkan fiqih al-Taysir sementara gabungan dua potongan itu menggambarkan moderasi dalam produk fiqih. Kalau kita merenungkan kaidah alGazali ini maka kita menemukan relevansinya dengan perangkat lain yaitu konsep Saddu alDzaraai dan Istihsaan.

\section{Saddu Al-Dzardi', Istihsan: Sebuah Ikhtiar Membangun Fiqih Dakwah}

Kalau kita menggunakan standar atau ukuran "fleksibilitas" dalam rangka mendeteksi kekuatan wacana atau fenomena moderasi dalam Islam, maka konsep Istihsan dan Saddu al-Dzariah merupakan lahan yang sangat subur bagi moderasi dalam Islam sekaligus menjadi mesin yang sangat efektif bagi pengembangan Dakwah. Ide yang menjadi muatan Istihsan adalah otoritas yang diberikan kepada seorang mujtahid untuk mengalihkan atau memindahkan hukum yang sudah tetap bagi suatu kasus tertentu dan diperkuat oleh ketentuan umum dalam hukum Islam untuk kemudian menetapkan hukum baru bagi kasus yang dimaksud karena ada pertimbangan-pertimbangan syar'i yang lain atau karena penerapan hukum yang pertama tidak lagi mengandung kemaslahatan atau penerapannya boleh jadi mendatangkan kemudaratan (Imam alSyatibi, $1995: 207$ ).

Untuk melihat posisi penting yang dimiliki konsep ini, bahkan berdasarkan sebuah riwat, Imam Malik mengatakan "Sembilan persepuluh (9/10) dari realitas fikih dibangun atas konsep istihsan". Riwayat lain dari seorang ulama mazhab Maliki, ia mengatakan, "siapa yang terlalu berlarut dalam menggunakan qiyas maka ia dikhawatirkan akan menyalahi Sunnah" ((Imam al-Syatibi, 1995 : 210). Tampaknya, statement ini dikemukakan dalam konteks penggunaan qiyas yang berlebihan karena ada anggapan bahwa qiyaslah yang lebih mendekati Nash (Teks) ketika hukum kasus baru tidak dijelaskan di dalam nash, padahal sikap berlebihan yang demikian berpotensi untuk mereduksi dimensi kemanusiaan dalam bangunan Hukum Islam. Seorang dai harus mengadopsi atau memanfaatkan fiqih al-lstihsan ketika ia menyampaikan dakwahnya di hadapan masyarakat moderen apakah melalui mimbar, radio, tv, internet, media cetak dll.

Demikian halnya pendekatan atau konsep saddu al-Dzariah, ia tidak kalah pentingnya dalam memperkaya misi dakwah melalui moderasi hukum Islam. Substansi yang terkandung dalam saddu al-Dzariah adalah menutup akses, sarana, atau jalan yang mengantarkan kepada kemafsadatan, atau kemudaratan. Sarana yang digunakan untuk terjadinya kemudaratan harus ditutup atau dilarang untuk dilakukan meskipun ia memiliki hukum kebolehan pada dasarnya, apa lagi kalau ia memang sudah diharamkan sejak awal. Dengan demikian, bisa dipahami bahwa ijtihad dapat memproduk hukum yang bertentangan secara kasat mata dengan hukum normal (awal) meskipun sesuai dengan substansi atau inti paling dalam dari ajaran hukum, dan inilah yang menjadi esensi konsep Saddu al-Dzariah dan Istihsan. Sisi lain dari Saddu al-Dzariah adalah otoritas yang diberikan kepada seorang mujtahid untuk membuka akses-akses atau jalan-jalan yang dapat membawa kepada terciptanya kemaslahatan atau kebaikan universal. Sisi yang menarik dari teori ini, karena seorang mujtahid diberi kewenangan untuk membuka akses kemaslahatan meskipun harus terpaksa menghalalkan yang dilarang dalam Islam. Contoh yang sering dikemukakan oleh pakar hukum adalah berbohong yang tadinya diharamkan dalam Islam, tapi dalam kasus-kasus tertentu dibolehkan demi menghindari terjadinya kemafsadatan.

\section{Karakteristik Moderasi Islam}

Setelah kita menggarisbawahi wacana dan fenomena moderasi secara seksama, maka untuk membangun dan memperkokoh bangunan moderasi Islam yang sudah terbangun, tampaknya kita harus mengemukaka'n kriteria atau karakteristik moderasi Islam untuk mendukung pengembangan dakwah Islam. Konsekwensinya, seseorang dapat dikatakan seorang muslim moderat, dai moderat 
sangat dipengaruhi oleh komitmennya pada kriteria atau karakteristik yang akan kita kemukakan seperti di bawah ini:

Pertama, pengakuan akan adanya tujuan hukum di balik teks-teks suci dan memperhatikannya ketika ingin memahami hukum atau pesan dari Nash. Karakteristik ini penulis istilahkan dengan substansialisasi ajaran Islam. Kedua, komitmen terhadap cara pemahaman teks atau hukum yang mengaitkannya dengan konteksnya (red: Asbdb al-Nuzul atau Asbdb al-Wuriid) yang penulis istilahkan dengan kontekstualisasi ajaran Islam. Ketiga, keberpihakan pada teori "TaW atau rasionalisasi hukum dalam bidang muamalah. Teori ini berbasis pada bahwa inti dari muamalah adalah kemaslahatan. Keempat, membedakan antara bidang ibadah dan muamalah. Kelima, membedakan antara Substansi ajaran dan Sarana.

\section{Dakwah dan Substansialisasi Ajaran Islam}

Karakteristik pertama yang harus diperhatikan oleh misi dan gerakan dakwah adalah pengakuannya terhadap adanya rahasia dan tujuantujuan luhur yang bergerak di balik ajaran-ajaran Islam dan mencari dengan segala daya upaya yang ia miliki sebelum ia menetapkan sebuah kebijakankebijakan dakwah. Ketika ia sudah mendapatkannya ia mengaktifkannya dalam proses memahami sebuah teks hukum. Ia tidak jumud pada permukaan (formalitas) sebuah teks tetapi ia menyelami teks itu dan kemudian memahami teks berdasarkan penyelaman makna di dasar-dasar teks. Ia selalu menghadirkan tujuan teks dan memandangnya sebagai sesuatu yang penting sebelum memberi interpretasi atau penjelasan mengenai teks.

Kalau kita mundur ke belakang untuk melihat kondisi fiqih sahabat, terapan-terapan teori substansialisasi ajaran Islam dapat ditemukan dengan mudah. Salah satu sampel yang dapat masuk dalam kategori ini adalah kasus Bani Quraidzah. Berdasarkan formalitas teks (hadis Nabi), para sahabat dilarang oleh Nabi untuk salat Ashar di jalan dan salat Ashar harus dilaksanakan di Bani Quraidzah. Hadis itu berbunyi "Laa Yushalliyanna Ahadukum al-Ashra Iliaft Bani Quraidzah" (HR alBukhar No: 904). Sejarah menuturkan tidak semua sahabat mengikuti perintah Nabi itu secara formal. Sebagian sahabat memilih salat Ashar sebelum sampai di Bani Quraidzah karena waktu Ashar sudah hampir habis, dan khawatir habis sebelum sampai di Bani Quraidzah. Pertanyaannya, kenapa kelompok sahabat yang dimaksud berani menyalahi perintah
Nabi? Jawabannya karena mereka menangkap substansi makna di balik larangan itu yaitu bahwa Nabi menginginkan agar sahabat bersegera, bercepat-cepat menuju tempat yang dituju. Harapan Nabi kalau itu dilakukan dapat diduga dengan kuat sahabat akan sampai di Bani Quraidzah jauh sebelum waktu Ashar habis. Pada titik ini kita dapat dengan mudah menemukan terapan substansialisasi ajaran Islam yang dimaksud. Kasuskasus kontemporer yang dapat dimasukkan sebagai terapan ini adalah hukum formalitas jenggot dan substansi "Pembedaan antara muslim-non muslim", dimana dalam sebuah riwayat Nabi memberi isyarat bahwa berjenggot saat itu dianjurkan sebagai sarana yang dapat membedakan antara kelompok muslim dari non muslim.

\section{Dakwah dan Kontekstualisasi Ajaran Islam}

Cir i khas yang keduayang mesti diperhatikan oleh gerakan dakwah adalah pengakuan dirinya atas teori kontekstualisasi Ajaran Islam. Inti dari teori ini adalah upaya melacak unsur-unsur sejarah yang melingkupi sebuah ajaran, kemudian memberi pengaruh bagi unsur-unsur itu bagi pemahaman atau penerapan sebuah ajaran atau hukum. Teori ini berasumsi bahwa sebuah hukum boleh jadi ditetapkan oleh Allah atau Nabi disebabkan karena kondisi atau keadaan tertentu yang menghendaki adanya hukum tertentu pula. Konsekwensinya, bila kondisi itu sudah berubah dan terjadi kondisi baru yang berbeda maka semestinya hukum yang dulu harus juga beruba pula dan digantikan dengan hukum baru atau kembali kepada hukum normal. Karena itulah, teori ini berasumsi bahwa siapa pun yang ingin memahami pesan yang terkandung dalam sebuah teks atau nash, maka pengetahuan tentang dua kondisi yaitu kondisi zaman turunnya wahyu atau kondisi zaman Nabi menuturkan hadisnya dan kondisi zaman sekarang adalah sebuah keharusan.

Kasus yang sesuai untuk menjadi contoh bagi teori ini adalah larangan Nabi bagi wanita untuk bepergian tanpa mahram. Kata Nabi, "Laa Tusaafirul Mar'atu Ilia ma'a Dzii Mahramin" (HR al-Bukhari, No: 1036) yang artinya seorang perempuan tidak boleh bepergian (melakukan perjalanan) tanpa mahram. Kalau formalitas hadis ini diterapkan maka seorang perempuan kemana saja ia pergi harus dikawal atau ditemani oleh suaminya atau saudaranya atau bapaknya. Kalau ini benar, maka perilaku wanita moderen yang hidup zaman sekarang sudah tidak sesuai dengan hadis tadi. 
Namun, apabila konsep kontekstualisasi ajaran kita gunakan untuk mengukur perilaku wanita sekarang maka kita dapat mengatakan bahwa apa yang dilakukan wanita zaman sekarang (bepergian tanpa mahram) bukanlah sebuah pelanggaran agama. Alasannya karena hadis yang melarang perempuan bepergian tanpa mahram dituturkan oleh Nabi karena konteks saat itu menghendakinya, dimana perjalanan seorang wanita sangat berbahaya bagi dirinya atau bagi reputasi baiknya. Hal itu mudah dipahami, karena jarak yang harus ditempuh seorang pejalan adalah padang pasir yang sangat riskan dengan binatang buas atau kelompok penjahat yang tidak bermoral, ditambah dengan alat transportasinya adalah unta. Dengan kata lain, konteks hadis larangan itu adalah konteks tidak aman, sehingga kalau ingin dibandingkan dengan konteks sekarang maka kita dapat mengatakan bahwa konteks hadis itu sudah berubah karena konteks sekarang adalah konteks aman. Seorang wanita yang ingin berangkat ke sebuah daerah misalnya tidak perlu dikawal oleh seorang mahramnya karena perjalanan sangat aman (Yusuf al-Qaradhawi, 2006:166). Dengan demikian, maka pada intinya teori kontekstualisasi ajaran ingin menyampaikan bahwa ada hukum-hukum yang dibangun oleh Rasulullah berdasarkan konteks zaman itu menghendakinya, dan boleh jadi konteks sekarang tidak menghendakinya, dan kemudian hukum-hukum itu tentu tidak bisa dipertahankan karena sudah kehilangan konteksnya. Untuk lebih memperdalam pengetahuan mengenai teori kontekstualisasi hukum dianjurkan merujuk ke gagasan yusuf al-Qaradhawi mengenai teori ini di berbagai bukunya diantaranya Kaifa Nata'amal Ma' al-Sunnah", Diraasah fi Fiqih Maqasid alSyariah Bain al-Maqasid al-Kulliyah wa al-Nusus al-Juziyyah. Dalam buku-buku yang dimaksud al-Qaradhawi banyak mengemukakan contoh kasus kontemporer yang bisa dijadikan bahan renungan betapa teori kontekstualisasi memiliki orisinalitas yang mengakar dalam tradisi salaf dan bukanlah teori baru.

Begitu besar pengaruh yang dimainkan teori ini dalam perkembangan pemikiran Islam terutama dalam bidang pengembangan hukum Islam, maka kita dapat mengatakan bahwa betapa banyak pendapat memiliki kekuatan pada zaman dulu, namun zaman sekarang menjadi lemah karena alasan bahwa pendapat-pendapat itu sudah kehilangan konteksnya.
Kontekstualisasi ajaran yang mengakar di dalam tradisi Nabi (Sunnah) telah banyak menginspirasi ulama-ulama yang datang kemudian. Salah seorang ulama yang cukup populer yang memiliki gagasan kuat mengenai teori ini adalah ulama yang bermazhab hanbali yakni Imam Ibn al-Qayyim. Dalam buku monumentalnya " I'lam alMuwaqqi'in, ia telah memberi ruang khusus (pasal) untuk mengkristalkan konsep kontekstualisasi fiqih Islam" dengan memberi judul ruang itu dengan "Tagayyur al-Fatwa Wakhtilafuha Bihasabi tagayyuri al-Azminati wa al-amkinati wa al-Ahwal wal al-Niyydt wal Awaid" yang artinya perubahan dan perbedaan fatwa karena perubahan zaman, tempat, kondisi, niat dan tradisi (Ibn al-Qayyim, 1973 vol 2 :. 425).

\section{Dakwah dan Rasionalisasi Ajaran Islam}

Ciri ketiga adalah keberpihakan gerakan dakwah terhadap konsep rasionalisasi ajaran. Konsep rasionalisasi Ajaran berbeda dengan konsep substansialisasi ajaran. Substansialisasi-seperti yang telah dikemukakan sebelumnya-adalah upaya yang dilakukan oleh seorang ulama untuk menentukan sasaran apa yang ingin dicapai oleh sebuah ajaran. Sementara yang dimaksud dengan Rasionalisasi ajaran adalah mencari kemudian menentukan faktor-faktor yang mempengaruhi ada atau tidaknya sebuah hukum yang terkandung di dalam sebuah teks. Mayoritas penulis muslim kontemporer merujuk ke term "Hikmah" untuk memaknai Substansialisasi dan merujuk ke term "Illat" untuk memaknai rasionalisasi. Untuk lebih mempermudah pemahaman mengenai hal ini, perlu dikemukakan contoh berikut; Islam membolehkan seorang muslim untuk melakukan jama' qashar atau kedua-duanya dalam sebuah perjalanan (safar). Islam mengaitkan antara hukum bolehnya menjama atau mengqashar dengan perjalanan karena pada biasanya seseorang mengalami kesulitan (masyaqqah) dalam perjalanan. Karena adanya kesulitan (masyaqqah) yang biasanya dialami oleh seorang muslim yang berjalan maka Islam ingin meniadakan masyaqqah itu dengan memberinya kemudahan yaitu jama atau qashar. Mengaitkan hukum jama atau qashar dengan adanya perjalanan berarti yang terjadi adalah rasionalisasi, tapi mengaitkannya dengan masyaqqah maka sesungguhnya yang terjadi adalah substansialisasi bukan rasionalisasi. Atau kita dapat menggunakan rasionalisasi makro untuk memaknai substansialisasi dan menggunakan rasionalisasi mikro untuk memaknai rasionalisasi. 
Untuk rasionalisasi makro ulama kita sering menjelaskannya dengan mengatakan bahwa kehadiran agama (Islam) sesungguhnya memiliki tujuan utama yaitu terciptanya kemaslahatan bagi umat manusia dan mencegah terjadinya kemafsadatan dan kemudaratan. Berdasarkan tujuan ini, seorang ulama sangat dianjurkan untuk selalu merujuk kepada kode etik 'kemaslahatan baik ketika ia melakukan rasionalisasi makro atau mikro.

\section{PENUTUP}

Setelah memaparkan potret riil tentang era globalisasi dengan berbagai isu yang melingkupinya dan perlunya umat Islam mendisain metode dan strategi dakwah yang harus menjadi inspirasi bagi masyarakat yang hidup di era ini. Dan setelah mempertimbangkan karakter masyarakat yang hidup di era globalisasi ini, maka artikel ini telah sampai kepada kesimpulan bahwa perubahan zaman dari babak ke babak berikutnya merupakan sebuah keniscayaan. Keniscayaan perubahan zaman turut mempengaruhi keniscayaan perubahan sosial masyarakat menghidupi sebuah zaman. Dalam konteks dakwah Islamiyah, umat Islam di zaman globalisasi saat ini sudah sangat jauh berbeda dengan zaman awal Islam. Karena itulah keberhasilan dakwah Islamiyah sesungguhnya sangat tergantung pada kemampuan gerakan dakwah memainkan metode dan strategi dakwah yang sesuai dengan karakter zamannya. Hal ini dikarenakan masyarakat moderen yang sudah terglobalkan memiliki karakter yang sudah sangat jauh berbeda dengan karakter masyarakat yang sederhana yang hidup di zaman awal Islam. Dengan demikian, gerakan dakwah mau atau tidak mau harus mempertimbangkan perbedaaan karakterkarakter yang dimaksud. Salah satu alasan kenapa Islam dapat dengan mudah diterima oleh komunitas dakwah adalah karena Islam telah mendeklarasikan dirinya sebagai ajaran yang moderat, sebuah ajaran yang mampu mengakomodir kebutuhan dan kemaslahatan manusia. Ajaran moderat harus ditumbuhkembangkan di era globalisasi ini oleh gerakan dakwah dengan tiga instrumen utama yakni substansialisasi ajaran, kontekstualisasi ajaran, dan rasionalisasi ajaran. Terapan-terapan konsep ini sangat banyak ditemukan dalam tradisi keilmuan kita, tidak terkecuali dalam tradisi dakwah.

\section{Ucapan Terima Kasih}

Artikel ini telah dipresentasikan pada Seminar Internasional on Dakwah Islamiyah in the Era of Globalisation yang diselenggrakan oleh Universiti Islam Sultan Syarif Ali (UNISS A) Brunei 2012, kami mengucapkan terima kasih kepada peserta seminar yang telah apresiasi, serta memberi saran dan kritik untuk penyempurnaan artikel ini. Penghargaan dan terima kasih yang sama kami tujukan kepada Dr.Abd.Rauf Amin, MA yang telah meluangkan waktunya untuk berdiskusi dan menelaah artikel ini, sebelum diajukan ke redaksi Al-Qalam.

\section{DAFTAR PUSTAKA}

Agustian, Ari Ginanjar. 2002. ESQ: Emotional Spiritual Quetiont. Cet. VI. Jakarta: Arga.

Atiyah, Jamaluddin 2002. al-Waqi' wa al-mitslfi alfikri al-islami al-mu'asir. Beirut: Darr al-hud.

Halim, Abdul El-Muhammady. 1992. Dinamika Dakwah Suatu Perspektif dari Zaman Awal Islam hingga Kini. Kuala Lumpur: Budaya Ilmu.

Jamilah, Maryam. 1983. Islam dalam Kancah Modernisasi. Bandung: NV Tarate.

al-Qardhawi, Yusuf. 2001. Islam dan Globalisasi Dunia. Jakarta: CVPustaka Al-Kautsar. 2007. Kalimaat fi al-Wasatiyyah al-Islamiyyah wa Ma'alimuha. Kuwait: alMarkaz al-Alami Lilwasatiyyah. 2007. Dirasah fi Fiqih Maqasid alSyariah. Kairo: Dar al-Syuruq.

al-Qayyim, Ibn. 1973. Vlaam al-Muwaqqi'in. Beirut: Dar -Aljil.

Rais, Amin. 1998. Tauhid Sosial. Cet. I. Bandung: Mizan.

Sardar, Ziauddin. 1996. 'Information and The Muslim World: A Strategy for The TwentyFirst Century', diterjemahkan oleh Priyono dengan judul Tantangan Dunia Islam Abad 21 Menjangkau Informasi. Cet. VII. Bandung: Mizan.

Shalabi, Muhammad Mustafa. Ta'lil al-Ahkam. Kairo: Dar al-Nahdah al-Arabiyyah.

al-Suyuthi. 1403H. Al-Asyban wa Al-Nazair Beirut: Dar al-Kuutb al-Ilmiyyah.

al-Syatibi. 1995. Al-Muafaqat. Beirut: Dar alIlmiyyah. 